\title{
Production of recombinant Scots pine defensin 1 and characterization of its antifungal activity
}

\author{
V. A. Kovaleva, R. T. Gout, I. T. Gout ${ }^{1}$ \\ National University of Forestry, Henerala Chuprynky 103, Lviv, 79057, Ukraine \\ ${ }^{1}$ University College London, Gower str., London, WCIE 6 BT, Great Britain
}

\begin{abstract}
We have recently reported affinity purification and molecular cloning of defensin (PsDef1, Pinus sylvestris defensin 1) from Scots pine germinating seeds. In this study, we describe subcloning of PsDefl mature form into bacterial expression vector pET $42 a(+)$ and the expression of recombinant GST/PsDef1 in Escherichia coli. The conditions for the expression and affinity purification of soluble GST/PsDef1GST were defined. Affinity purification of the recombinant GST/PsDef1 on glutathione-sepharose column and proteolytic removal of GST moiety with Factor Xa allowed us to generate functionally active preparations of recombinant PsDef1. Moreover, the antimicrobial activity of recombinant PsDef1 was found to be comparable to that of endogenous Scots pine defensin.
\end{abstract}

Keywords: recombinant defensin PsDef1, expression, affinity purification, antifungal activity.

Introduction. Defensins are evolutionally conservative molecules of innate immunity of plants, mollusks, insects and animals which are characterized by small size $(<10 \mathrm{kD})$, and amphipathic, $\beta$-layers-rich structure and stabilized disulfide bridges $[1,2]$. These secretory proteins (peptides) are synthesized as precursors with further removal of signal peptides. The mature form of defensins from different species has antimicrobial properties [3].

Defensins are widely spread in plant kingdom and could be purified from seeds, vegetative and generative organs of many angiosperm species. The genes of these defensive proteins are expressed constitutively or under the influence of biotical factors in the peripheral cell layers, forming the first defensive line against pathogens $[4,5]$. Plant defensins possess broad range of biological activities, including antifungal $[3,5,6]$, antibacterial [7], inhibiting of proteinases and $\alpha$-amylases [8, 9] and blocking of $\mathrm{Ca}^{2+}$ and $\mathrm{Na}^{+}$-channels [10].

(C) V. A. KOVAleVA, R. T. GOUT, I. T. GOUT, 2008
Elucidation of biological properties of plant defensins by in vitro studies has been well complimented by studies with the use of transgenic plants. Research from several laboratories provided the evidence that overexpression of defensins results in the increase of the resistance to pathogenic infections which remains effective over several generations. For examples, constitutive expression of radish defensin RsAFP2 in tobacco increases plant's resistance against fungal infection by Alternaria longipes and A. solani, which affects the leaves. Moreover, the expression of Medicago sativa defensin in the potatoes provided a robust resistance against pathogenic fungus of Verticillium dahliae [11].

It is necessary to note the most studies on the function of plant defensins have been performed using the models of Arabidopsis thaliana and crops [12]. The molecular mechanisms of antimicrobial resistance in long-lived plants, including wood species, have not been elucidated clearly so far [13].

The recent studies from our laboratory have provided the evidence that defensin from the Scots pine 
seedlings has the potential to bind efficiently and specifically to phosphotyrosine matrixes. The results of mass spectrometry analysis of purified defensin provided us the data required for the molecular cloning of Pinus sylvestris defensin, which we termed PsDef1. A cDNA clone, corresponding to PsDef1 (Acc. No. EF455616), was isolated from a cDNA library of seven-days old Scots pine seedlings, which was generated in our laboratory. The molecular studies allowed us to deduct the amino acid sequence of defensin 1 and to carry out a comparative analysis of its primary structure and properties with defensins from various plants $[16,17]$.

In addition, we have developed a new protocol for the purification of endogenous defensin from Scots pine seedlings and demonstrated its antifungal properties $[14$, 15]. To further advance our knowledge on biological properties of defensin 1, we have focused out research on generating large quantities of recombinant PsDefl and producing specific polyclonal and monoclonal antibodies. The high level of protein production can be achieved by employing prokaryotic expression system, using GST or His-tag fusions and Escherichia coli. Here, we describe for the first time construction of an expressing plasmid coding for GST/ PsDef1 fusion protein, affinity purification of recombinant protein and the removal of GST moiety by proteolytic cleavage with Factor $\mathrm{X}$. The resulting preparation of mature form of PsDefl was shown to possess antibacterial properties which are comparable to those of endogenous defensin purified from Scots pine seedlings.

Materials and methods. The expression vector pET42a $(+)$ ('Novagen', USA) and E. coli strains XL-1 Blue and BL21 (DE3) have been used for cloning and expression studies. The phytopathogenic fungus cultures of Fusarium oxysporum YKM F-52897, F. solani YKM F-50639, Botrytis cinerea YKM F-16753, Altermaria alternate YKM F-16752 and phytopathogenic bacteria of Erwinia carotovora YKM B-1075 have been kindly provided by D.K. Zabolotny Institute of Microbiology and Virology, National Academy of Sciences of Ukraine. The necrotrophic fungus culture of Heterobasidion annosum has been kindly provided by Dr. V. Kramarec (Lviv National Forestry University of Ukraine). The culture of oomicete Pythium dimorphum has been obtained from the Institute of Forestry Research (IBL, Poland).
Cloning of mature form of Scots pine defensin into pET42a(+) vector. A fragment of cDNA corresponding to mature form (basic domain) of Scots pine defensin 1 (mPsDefl) was amplified by polymerase chain reaction (PCR) using a template cDNA clone for defensin 1 and two primers: direct primer CR765 (5'-CCATTCCATGGGAATGTGCAAAACCCCCA G-3') which contains nucleotide sequences corresponding to restriction endonuclease NcoI, followed by initiating Met and Gly instead of Arg at the N-terminus of mature form of Scots pine defensin 1; reverse primer CR764 (5'-CATGAGAATTCTCAAGGGCA GGGTTTGTA-3') includes nucleotide sequences for restriction endonuclease EcoRI, stop-codon and 3'coding fragment of defensin 1.

The conditions for PCR amplification have been described previously [17]. PCR products were analyzed by $1.5 \%$ agarose gel electrophoresis in Tris-borate buffer, $\mathrm{pH} 8.3$ (50 mM Tris- $\mathrm{H}_{3} \mathrm{BO}_{3}, 2 \mathrm{mM}$ EDTA) under $20 \mathrm{~V} / \mathrm{sm}^{2}$. Amplified products were eluated from the gel with the use of a gel extraction kit from Qiagen (USA). Purified DNA and pET42a $(+)$ vector have been hydrolyzed with restrictases NcoI/EcoRI and then precipitated using a standard method [18]. The T4 DNA-ligase ('Fermentas', Lithuania) was used for linking amplified cDNA fragment of defensin 1 into pET42a $(+)$ vector in frame with the N-terminally located GST. The products of ligation were transformed in to XL-1 Blue competent cells. The plasmid purification kit was used to purify plasmid DNA from antibiotic resistant colonies. The presence of PsDef1 cDNA insert in purified plasmids was detected by restriction analysis with endonucleases XhoI and EcoRI as well as by PCR analysis with primers of C765 and CR764. The sequence of amplified PsDef1 in three resulting plasmids was verified by sequence analysis on automatic DNA sequencer ABI 73 TM.

The expression of recombinant PsDef1 in bacterial system E. coli. BL21(DE3) competent cells were transformed with $\mathrm{pET} 42 \mathrm{a} / \mathrm{mPsDef1}$ construct and obtained colonies were grown at $37^{\circ} \mathrm{C}$ in LB-medium containing $50 \mu \mathrm{g} / \mathrm{ml}$ kanamycin. When the optical density of bacterial cultures reached $\mathrm{A} 600=0.6,0.4 \mathrm{mM}$ isopropyl-thiogalactosid (IPTG) was added to induce the expression of recombinant protein. After the incubation of induced cultures for 2 hours, bacterial cells 
were collected by centrifugation at $4000 \mathrm{~g}$ for $20 \mathrm{~min}$ utes. The pellet of bacteria was washed with ice-cold PBS, frozen and preserved at $-70 \mathrm{C}$.

The purification of recombinant PsDef1 conjugated with glutathion-S-transferase by affinity chromatography. All purification steps were performed at 4 C. Cell pellet ( $2.5 \mathrm{~g}$ ) was resuspend and lysed in $15 \mathrm{ml}$ buffer A, consisting of: $10 \mathrm{mM}$ Tris-HCl, $(\mathrm{pH} 7.5), 150$ $\mathrm{mM} \mathrm{NaCl}, 50 \mathrm{mM} \mathrm{NaF}, 5 \mathrm{mM}$ EDTA, 1\% Triton $\mathrm{X}-100,1 \mathrm{mM}$ PMSF with proteinase cocktail of inhibitors ('Roche', France). Cells were destroyed by mechanical grinding in a homogenizer. The lysate of cells was centrifuged at $17000 \mathrm{~g}$ for $20 \mathrm{~min}$. The supernatant was incubated on the wheel for 2 hours with a $50 \%$ suspension of Glutathione-sepharose ('Amersham', Great Britain), pre-washed in buffer A. The beads were washed on the wheel with $50 \mathrm{mM}$ Tris- $\mathrm{HCl},(\mathrm{pH} 7.5)$, $150 \mathrm{mM} \mathrm{NaCl}$ with $0.05 \%$ of Twin-20 three times for 5 minutes and twice with $50 \mathrm{mM}$ Tris- $\mathrm{HCl},(\mathrm{pH} 8.0)$.

Bound proteins were eluated from Glutathione-sepharose with $50 \mathrm{mM}$ reduced glutathione in $50 \mathrm{mM}$ Tris- $\mathrm{HCl},(\mathrm{pH} 8.0), 150 \mathrm{mM}$ $\mathrm{NaCl}$. The eluted fractions were analysed by Bradford assay to measure protein concentrations and by SDS-PAGE for examining the quality of purified GST-PsDef1. The fractions, which contained GST-PsDef1 were combined and dialyzed against buffer B, containing $20 \mathrm{mM}$ Tris- $\mathrm{HCl}(\mathrm{pH} 7.5), 150$ $\mathrm{mM} \mathrm{NaCl}, 1 \mathrm{mM}$ DTT, in order to remove glutathione. The concentration of generated preparations of GST-PsDef1 was measured by Bradford assay. Produced GST-PsDef1 was stored at $-20 \mathrm{C}$ in presence of 50\% glycerol.

Production of mature form of PsDef1. The Factor $\mathrm{X}_{\alpha}$ ('Sigma', USA) was used to cleave recombinant Scots pine defensin (PsDef1) from the fusion polypeptide GST-PsDef1. In brief, GST-PsDef1 was sorbed on the glutathione-sepharose and equilibrated with buffer containing $50 \mathrm{mM}$ Tris- $\mathrm{HCl}$ (pH 8.0), 100 $\mathrm{mM} \mathrm{NaCl}, 2 \mathrm{mM} \mathrm{CaCl}_{2}$. Then, Factor $\mathrm{X}_{\alpha}$ was added at the concentration of $2 \mu \mathrm{g}$ per 100 micrograms of GST-PsDef1. The reaction was performed under room temperature for 5 hours on the wheel. Beads were then collected by centrifugation at $3000 \mathrm{~g}$ for 1 minute. The supernatant liquid was collected and loaded onto Centricon YM 30 ('Millipore', USA) for concentration at $10000 \mathrm{~g}$. The filtrate was collected and protein concentration measured by Bradford assay and analyzed by SDS-electrophoresis in 15\% PAAG in a Tris-tricine buffer system [19].

Antimicrobial activity of Scots pine recombinant defensin 1 assay. To study the activity of generate preparations of recombinant defensin 1 the pieces of fungus mycelium were placed into the center of Petri dishes $(90 \times 15 \mathrm{~mm})$ with $1.8 \%$ potato-dextrose agar. When the diameter of fungus colony had reached $3 \mathrm{~cm}$ the sterile discs of filter paper were placed onto the agar $0.5 \mathrm{~cm}$ away from the colony edge. The aliquots $(100 \mu \mathrm{l})$ of different protein concentrations of PsDef1 were applied on the paper discs. Distilled water has been used as a negative control and different concentrations of endogenous defensin purified from Scots pine seedlings were also tested. The plates were then incubated at $23{ }^{\circ} \mathrm{C}$ until mycelium enveloped the disks with control solution, while growth-inhibiting zones were formed around the discs containing recombinant defensin 1 .

A quantitative analysis of the antifungal activity of Scots pine defensin was performed as previously described [20]. The spores were extracted from sporulating fungus cultures, which have been grown on the 1.8\%-potato-dextose agar. The spore suspension has been filtered with double layer of sterile gauze. 80 microlitres of spore suspension $\left(2 \times 10^{4}\right.$ spores $\left./ \mathrm{ml}\right)$ in potato-dextrose broth and 20 microlitres of sterile defensin solution (with concentrations $0.2,0.5,1,5,10$ $\mu \mathrm{g} / \mathrm{ml}$ ) were added into the wells of 96 -well microtiter plate. The plates were incubated in dark at $23 \mathrm{C}$. The test sample consisted of 20 millilitres of sterile distillated water. After 48 hours of incubation, the optical density of fungal suspension was measured in each well under $595 \mathrm{~nm}$.

Results and discussion. The presence of an endoplasmic reticulum signal peptide, which is removed during the protein processing, is a feature of all plant defensins [3]. The sequence analysis of PsDef1 cDNA clones indicated an open reading frame of 83 amino acid residues. The first 33 aa correspond to the $\mathrm{N}$-terminal signal peptide and remaining 50aa form a basic domain of mature defensin. To produce large quantities of recombinant mature form of defensin 1 we decided to employ bacterial expression system of E. coli, as it allows efficient, fast and relatively inexpen- 


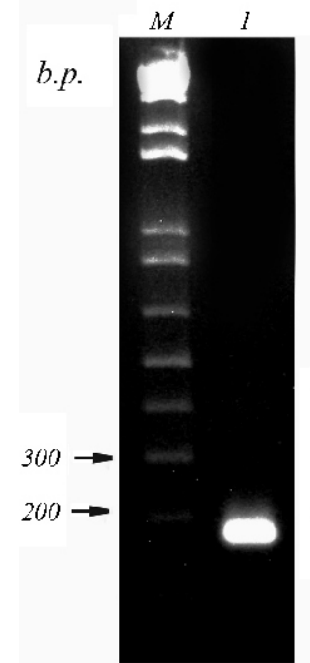

$a$

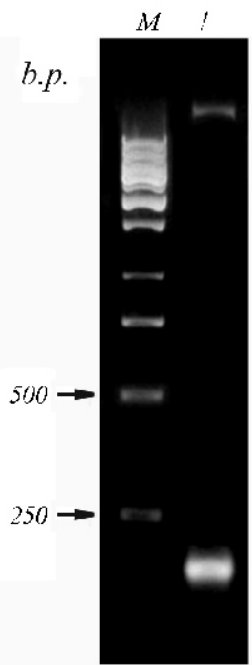

$b$

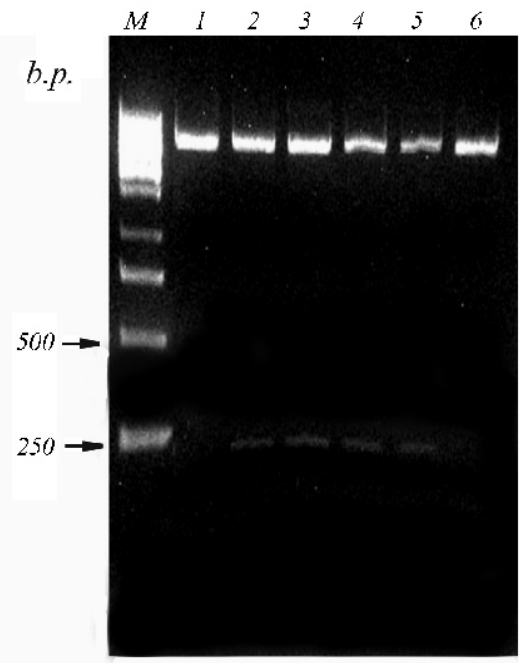

$c$

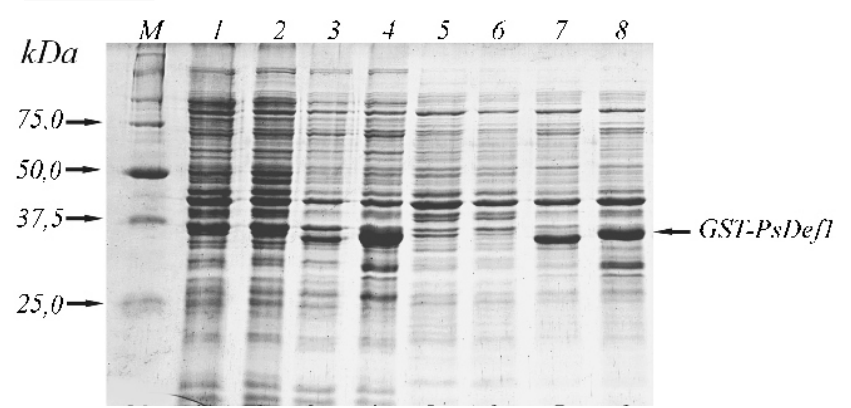

Fig.2. SDS-PAAG results of GST-PsDef1 exspession in E. coli BL21(DE3) strain: 1, 2, 3, 4 - fractions of the total cell lysates; 5, 6, 7, 8 - triton-soluble protein fractions; $\mathrm{M}$ - broad-range protein standards BioRad. Lanes 1, 2, 5, 6 -uninduced bacterial cultures; 3, $4,7,8$ - proteins from the cells induced by the addition of IPTG; 1 , $3,5,7$ - the cells transformed by plasmid without insert; 2, 4, 6, 8 -the cells, transformed by recombinant vector. Amount of proteins on each of the lines is equivalent to the $100 \mu 1$ cell suspension.

sive way of generating recombinant protein. Since the eukaryotic signal sequence is not recognized in the prokaryotic system, we have cloned a DNA fragment, coding the mature form of PsDef1 into bacterial expression vector.

A DNA fragment, corresponding to mature form of mPsDef1, was amplified by PCR using PsDef1 cDNA as a template and two specific primers. Agarose gel electrophoretic analysis of PCR products revealed a major band of approximately $200 \mathrm{bp}$ which closely correlates to expected size of $174 \mathrm{bp}$. (Figure 1, a). The product of amplification was digested with $\mathrm{NcoI}$ and XhoI and ligated into linearized pET42a $(+)$ vector. The XL-1 Blue competent cells were transformed with the ligation mix and plated for antibiotic selection. Plasmid
Fig.1. Cloning of a cDNA fragment encoding mature form of the Scots pine defensin 1: (a) 1 the products of PCR amplification of cDNA PsDef1; M - 1 kb Plus DNA Ladder GibcoBRL; (b) the analysis of $\mathrm{pET} 42 \mathrm{a} / \mathrm{mPsDef} 1$ plasmid by PCR (lane 1); M - 1 kb DNA Ladder Fermentas; (c) restriction analysis of pET42a/mPsDef1 plasmid using endonucleases Xho 1 and Nco 1 (lane 1); M - 1 kb DNA Ladder Fermentas.
DNA was purified from colonies grown on agar plates containing kanamycin. The presence of PsDef1 insert in purified plasmid DNAs was analysed by PCR amplification (Figure 1b) and restriction analysis with NcoI and XhoI endonuclease (Figure 1c). The obtained results clearly indicate that PsDefl cDNA is present in 4 out of 6 plasmid preparations.

To study expression the BL21 (DE3) competent cells were transformed by the generated pET42a/mPsDef1 plasmid. In parallel, the vector (pET42a alone) was also introduced into the BL21 (DE3) competent cells. The expression of recombinant GST-PsDef1 was induced in BL21 (DE3) by the addition of $1 \mathrm{mM}$ IPTG. The SDS-PAGE analysis of total lysates from inducted cells revealed the presence of recombinant protein of an expected molecular weight, $35.5 \mathrm{kD}$ (Figure 2). This analysis also showed that GST-PsDef1 fusion protein is soluble in buffer containing $1 \%$ Triton X-100. We also found that total cell lysate contained approximately $15 \%$ of GST-PsDef1 fusion proteins. Notably, some amounts of GST-PsDef1 were also observed among detergent-insoluble proteins.

Taking into account that recombinant GST-PsDef1 was found in both Triton soluble and insoluble fractions, in the form of inclusion bodies, we focused our efforts on optimizing the conditions for generating culturing maximum level of triton-soluble GST-PsDef1. By testing various temperatures for the expression of GST-PsDef1 we found that the optimal temperature for 

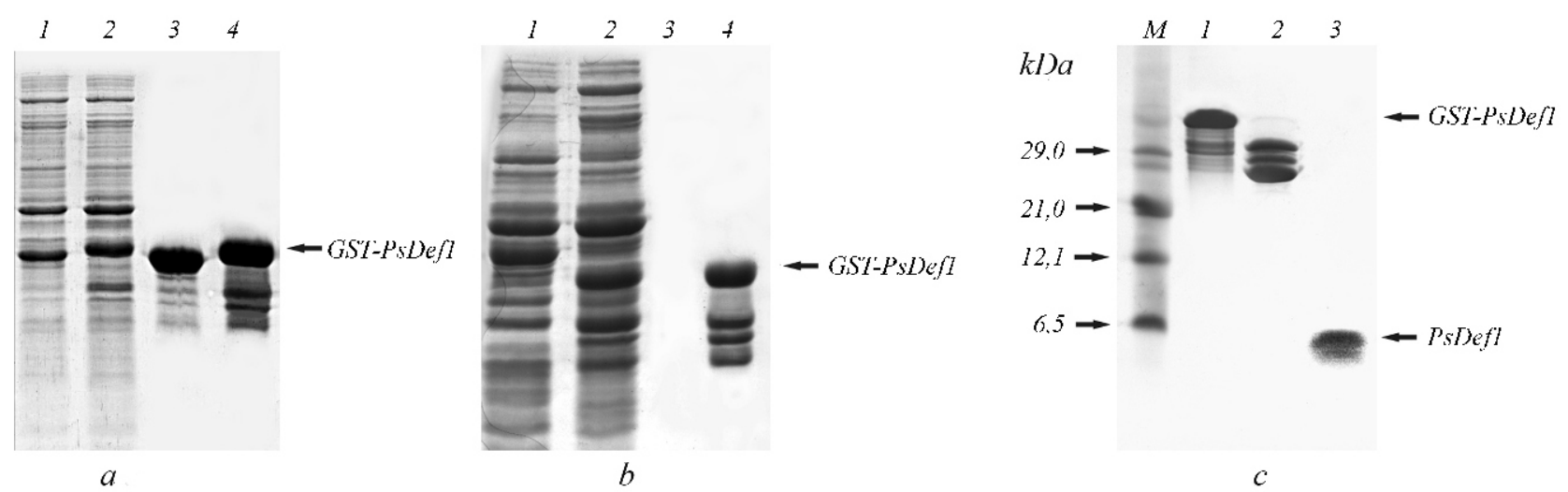

Fig.3. Isolation of the recombinant Scots pine defensin 1 from the E. coli BL21(DE3) cell lysates: (a) purification of recombinant GST?PsDef1 onto affinity sorbent: 1, 2 - triton-soluble proteins from the cells transformed by pET-42a and pET-42a-PsDef1 plasmids, respectively; 3 - GST preparation; 4 - GST-PsDef1 preparation; (b) 1, 2 - triton-soluble proteins from the uninduced and induced cells transformed by pET-42a/mDefl plasmid, respectively; 3, 4-proteins that bound to glutathione-Sepharose from lysates of the uninduced and IPTG-induced cells, respectively. Proteins were separated by $12 \%$ SDS-PAAG electrophoresis in Laemmle's system; (c) ? fractions after the proteolytic digestion of GST- PsDef1 with Xa factor: 1, 2 - immobilized proteins on glutathione-Sepharose before and after digestion, respectively. $15 \%$ Tricine-SDS-PAAG was performed for separation of each fraction. Gels were stained by Coomassie G-250.

generating the highest level of recombinant GST-PsDef1 is $37^{\circ} \mathrm{C}$, while lowering the induction temperature to $28-30^{\circ} \mathrm{C}$ (often used in order to fold polypeptide chain of recombinant product correctly) resulted in noticeable reduction of triton-soluble recombinant protein. The same effect was noticed with the increase of the induction time. In summary, the optimal expression of soluble GST-PsDefl was achieved by incubating transformed cells with $0.4 \mathrm{mM}$ IPTG for 2 hours at $37^{\circ} \mathrm{C}$.

The use of pET42a expression plasmid implied the production of recombinant PsDef1, conjugated with GST. The expression of PsDef1 fused to GST allowed us to employ affinity chromatography on glutathione-sepharose. As shown in Figure 3a, affinity purification from cells expressing plasmid alone or pET42a/mPsDefl results in highly enriched preparations of GST and GST-PsDef1 respectively. Both preparations contain some minor bands which exhibit similar pattern in both samples. In order to eliminate the possibility of non-specific protein sorbtion onto glutathione-sepharose, we incubated affinity beads with Triton-soluble proteins of uninduced cells. The results presented in Figure $3 \mathrm{~b}$ (lane 3), show very little of non-specific binding to Glutatione sepharose from lysates of uninduced cells. We have also eliminated the possibility that observed minor bands are binding partners of recombinant GST and GST-PsDef1, as they were not eluted from the affinity matrixes in the presence of $0.5 \mathrm{M} \mathrm{NaCl}$, but were readily eluated with 50 $\mathrm{mM}$ of reduced glutathione. As seen in the spectrum of triton-soluble proteins (Figure 3b, lanes 1 and 2) minor bands appear only after the induction of recombinant proteins. Therefore, the minor proteins are the products of either degradation or incomplete translation of GST-PsDef1. The affinity purified preparations of recombinant GST-PsDef1 contained approximately $75 \%$ the fusion protein.

The GST-PsDef1 fusion protein has molecular mass of approximately $35.5 \mathrm{kDa}$. The fusion consists of 220 amino acids of GST at the N-terminus and 51aa corresponding to mature form of PsDef1. There is also a 58aa insert between GST and PsDef1, which contains Factor $\mathrm{X}$ restriction site and some sequences from pET42a vector. Factor $X_{\alpha}$ is a serine proteinase, which recognizes and hydrolyzes the sequences of Ile Glu Gly Arg after certain amino acid sequences. The cloning strategy of pET42a/PsDef1 expression vector allows proteolytic removal of the mature form of PsDef1, consisting of 52 amino-acids, where the first two amino acids are the initiating methionine and then glycine instead of arginine.

To remove GST moiety from the GST-PsDeflfusion protein, we tested two cleavage protocols. Variant A: the cleavage of recombinant GST-PsDef1 with Factor $\mathrm{X}_{\alpha}$ was carried out in solution. 

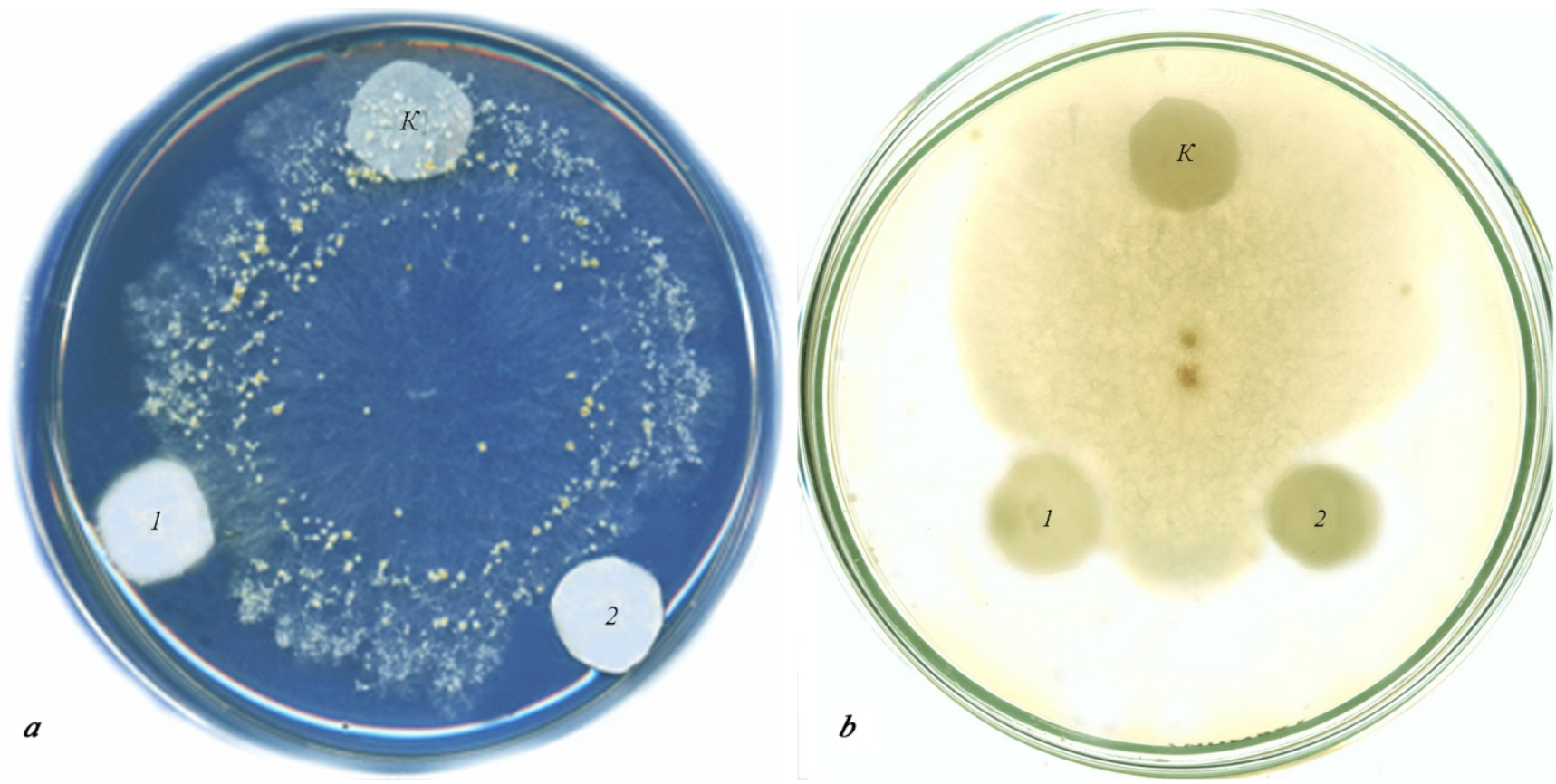

Fig.4. Inhibitory effect of purified recombinant PsDef1 on the growth of Heterobasidion annosum (a) and Fusarium solani (b): K - the sterile distilled water; $1-5 \mu \mathrm{g}$ of preparation; $2-10 \mu \mathrm{g}$ of preparation.

The removal of cleaved GST was performed on Glutathione-sepharose. The separation of Factor $\mathrm{X}_{\alpha}$ from cleaved PsDef1was carried out by centrifugation on Centricon YM 30 columns ('Millipore').

Variant B: proteolysis of the GST-PsDef1 fusion protein was performed on Glutathione sepharose. Here, Factor $\mathrm{X}_{\alpha}$ was added to the Glutathione-sepharose suspension with immobilized recombinant GST-PsDef1. After the cleavage, PsDef1 was released into solution, which was then processed for the removal of Factor $\mathrm{X}_{\alpha}$ proteinase as described above. Having both protocols compared, we found that the cleavage on beads is faster, more economical and allows greater output of PsDef1 protein.

Further studies indicated that optimal cleavage of GST-PsDef1 requires $20 \mathrm{mkg}$ of Factor $\mathrm{X}_{\alpha}$ per $1 \mathrm{mg}$ of fusion protein. The time-course analysis of Factor $\mathrm{X}_{\alpha}$ cleavage showed that full cleavage of GST-PsDef1 requires 5 hours at room temperature (Figure 3, c). As seen in lane 2, the band corresponding to the GST-PsDef1 fusion disappear after $5 \mathrm{hrs}$ of digestion, while the major band of approximately $30 \mathrm{kDa}$, which correspond to GST alone, is clearly detected.

So, the protocol designed for Factor $\mathrm{X}_{\alpha}$ cleavage of GST-PsDef1 allows the production of homogeneous preparations of recombinant PsDef1. The final output of PsDef1was approximately $10 \%$ from total GST/PsDef1 fusion protein, immobilized on Glutathione-sepharose.

The activity of recombinant proteins depends on correct folding of their polypeptide chain. Tertiary structure of plant defensin consists of three antiparallel $\beta$-sheets and an $\alpha$-helix, stabilized with 4 disulfide bridges. So, the activity of recombinant defensin could be lost from inadequate formation of -Cys-Cys pairs. The study of mechanisms of action of plant defensins, performed in the Braeckert group [23], revealed significant role of two regions in Rs-AFP2 which mediated the interaction with receptors on the fungus membrane. These regions are formed by amino acid residues, located in different parts of the polypeptide chain. For example, one region involves Thr10, Ser12, Leu28 and Phe 49. The site-directed substitution of these amino acids with amino residues which disturbe the 3D structure of defensin, leads to the loss of antifungal activity.

Next, we tested the antifungal activity of recombinant GST-PsDef1 and cleaved PsDef1. In this study, we used the fungi from the genus of Fusarium. No antifungal activity was observed in the presence of recombinant GST/PsDef1 (even, when the concentration 


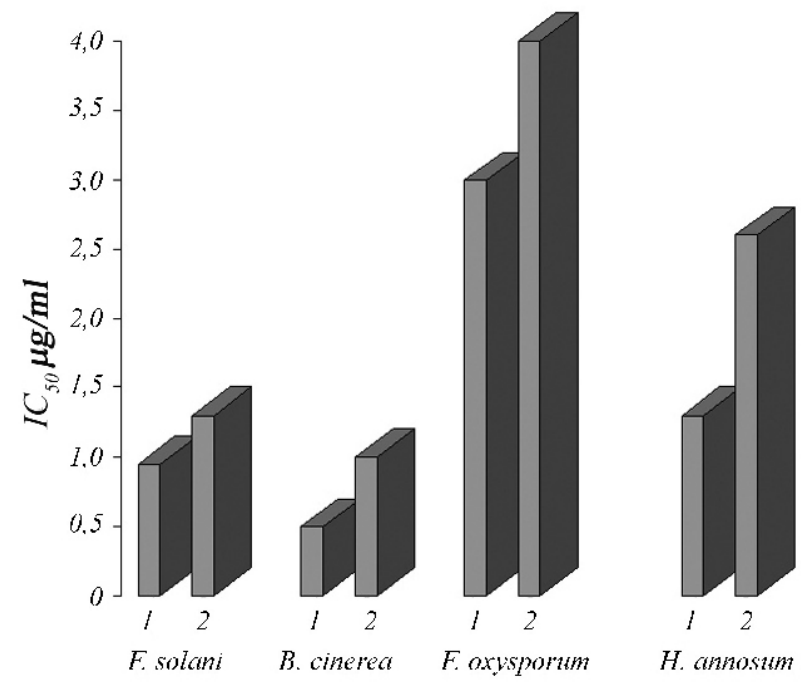

Fig.5. Comparative analysis of the antifungal activity of the endogenous PsDef1(1) with that of its recombinant analog (2).

of GST/PsDef1 in the culture medium was $50 \mathrm{mg} / \mathrm{ml}$ ). When, the activity of PsDef1 was tested in the growth inhibiting assay, we reproducibly observed strong antifungal properties of generated preparations of PsDef1. The antifungal activity was measured by the formation of zones, where the growth of mycelium of $H$. annosum and $F$ solani was inhibited (picture 4 ).

These findings provided the visual evidence for the inhibition of fungal growth by recombinant PsDef1. The next task was to develop the assay which would allow the quantitation of PsDef1 antifungal activity. To do so, we employed the microspectrophotometric method in which the optical density of fungi spore suspension was measured after 48 hours of incubation in potato-dextrose broth, containing various concentrations of recombinant defensin. When maximum concentration (4 micrograms/milliliter) of PsDef1 was used, the inhibition of fungal growth was: for $F$ solani by $81 \%$, for $F$ oxysporum by $50 \%$, for $H$ annosum by $71 \%$, for Pythium dimorphum by $84 \%$. These results indicate differential activity of recombinant PsDef1 towards different fungi. Differential inhibitory effect of plant defensins towards different fungi species has been previously described [24].

The activity of antimicrobial preparations is measured by the value of $\mathrm{IC}_{50}$. We have estimated $\mathrm{IC}_{50}$ of recombinant PsDef1 for $F$ solani, $F$ oxysporum, $B$. cinerea, and $P$. dimorphum. Their rates are 1.4, 4.0,
2.6, 1.2, 2.0 micrograms per milliliter respectively. The defensin PgD1 from Picea glauca, which exhibits 80\% identity to PsDef1, has been recently expressed in bacterial system and its antimicrobial activity has been studied. The purified recombinant preparations of PgD1 inhibited the growth of F. oxysporum by $95.2 \%$, which is similar to that of Scots pine defensin 1 [25].

In previous studies, we researched the antifungal activity of endogenous defensin purified from Scots pine seedlings $[15,26]$. These results allowed us to compare the values of $\mathrm{IC}_{50}$ for recombinant and endogenous defensin. The results of this comparative analysis are represented in the diagram of Figure 5. We found that the activity of recombinant PsDef1 is $1.5-2$ times lower then that of endogenous defensin from seedlings. This is probably the result of partial proteolysis of PsDef1 at Gly-Arg44 site, which might be recognised by Factor $\mathrm{X}_{\alpha}$.

In summary, we described for the first time the expression and affinity purification of recombinant defensin 1 from Scots pine possessing a strong antifungal activity. The availability of recombinant PsDef1 provides us with an excellent opportunity to study biochemical and functional properties of plant defensins and to elucidate molecular mechanisms of their action. In addition, recombinant preparation of PsDefl will be used for making specific polyclonal and monoclonal antibodies and to study the expression profile of defensin 1 in response to various growth-regulatory agents and pathogenic organisms.

\section{В. А. Ковальова, Р. Т. Гут, І. Т. Гут}

Отримання рекомбінантного дефензину 1 сосни звичайної та його антифунгальна активність

Резюме

Нещодавно нами очищено ендогенний дерензин із проростків сосни звичайної, а також клоновано кДНК, яка кодує дефензин 1 (PsDef1, Pinus sylvestris дефензин 1). Фрагмент кДНК дефензину 1 , який кодує зрілу форму цьього білка, клоновано у вектор pET42a(+) та індуковано його експресію у бактеріальній системі Escherichia coli. Оптимізовано умови продукування рекомбінантного білка PsDefl, злитого 3 глутатіон-S-трансферазою, у розчинній формі. Після афінного очищення иього білка на глутатіон-сефарозі та протеолізу фактором $X_{a}$ отримано біологічно активний препарат рекомбінантного PsDefl, антифунгальна активність якого співмірна з такою ендогенного дефензину 1 сосни звичайної.

Ключові слова: рекомбінантний дефензин PsDefl, експресія, афінне очищення, антифунгальна активність. 


\section{В. А. Ковалева, Р. Т. Гут, И. Т. Гут}

Получение рекомбинантного дефензина 1 сосны обыкновенной и его антифунгальная активность

Резюме

Ранее нами очищен эндогенный дефензин из проростков сосны обыкновенной, а также клонирована кДНК, кодируюшая дерензин 1 (PsDef1, Pinus sylvestris дефензин 1). Фрагмент кДНК дефензина 1, кодирующий зрелую форму этого белка, клонирован 8 вектор рЕT42а(+) и индуичрована его экспрессия в бактериальной системе Escherichia coli. Оптимизированы условия продукuзи рекомбинантного белка PsDefl, слитого c глутатион-S-трансферазой, в растворимой форме. После аффинной очистки этого белка на глутатион-сефарозе и протеолиза фактором $X_{a}$ получен биологически активный препарат рекомбинантного PSDefl, антифунгальная активность которого соизмерима з таковой эндогенного дефензина 1 сосны обыкновенной.

Ключевые слова: рекомбинантный дефензин PsDef1, экспрессия, аффинная очистка, антифунгальная активность.

\section{REFERENCES}

1. Broekaert W., Cammue B., DeBolle M., Thevissen K., DeSamblanx G., Osborn R. Antimicrobial peptides from plants // Crit. Rev. Plant Sci.-1997.-16.-P. 297-323.

2. Погрібний П. В. Ендогенні пептидні антибіотики як фактори імунітету тварин // Біополімери і клітина.-1998.-14, № 6.-C. 512-518.

3. Thomma B., Cammue B., Thevissen K. Plant defensins // Planta.-2002.-216.-P. 193-202.

4. Broekaert W., Terras F., Cammue B., Osborn R. Plant defensins: novel antimicrobial peptides as components of the host defense system // Plant Physiol.-1995.-108.P. 1353-1358.

5. Almeida M., Cabral K., Zingali R., Kurtenbach E. Characterization of two novel defense peptides from pea (Pisum sativum) seeds // Arch. Biochem. Biophys.-2000.378.-P. 278-286.

6. Terras F., Schoofs H., de Bolle M., Van Leuven F., Rees S., Vanderleyden J., Cammue B. P., Broekaert W. F. Analysis of two novel classes of plant antifungal proteins from radish (Raphanus sativus L.) seeds // J. Biol. Chem.-1992.267.-P.15301-15309.

7. Segura A., Moreno M., Molina A., Garcia-Olmedo F. Novel defensin subfamily from spinach (Spinacia oleracea) // FEBS Lett.-1998.-435.- P. 159-162.

8. Bloch C., Richardson M. A new family of small $(5 \mathrm{kDa})$ protein inhibitors of insect $\alpha$-amylases from seeds or sorghum (Sorghum bicolor (L.) Moench.) have sequence homologies with wheat - purothionins // FEBS Lett.-1991.279.-P. 101-104.

9. Wijaya R., Neumann G., Condron R., Hughes A., Polya G. Defense proteins from seed of Cassia fistula include a lipid transfer protein homologue and a protease inhibitory plant defensin // Plant Sci.-2000.-159.- P. 243-255.

10. Lay F. T., Anderson M. A. Defensin - components of the innate immune system in plants // Curr. Prot. Pept. Sci.2005.-6.- P. 85-101.

11. Gao A. G., Hakimi S. M., Mittanck C. A., Wu Y., Woerner B. M., Stark D. M., Shah D. M., Liang J., Rommens C. M. Fungal pathogen protection in potato by expression of a plant defensin peptide // Nat. Biotechnol.-2000.-18.-P. 1307-1310.

12. Thomma B., Broekaert $W$. Tissue-specific expression of plant defensin genes PDF2.1 and PDF2.2 in Arabidopsis thaliana // Plant Physiol. Biochem.-1998.-36.-P. 533-537.

13. Asiegbu F., Nahalkova J., Li G. Pathogen-inducible cDNAs from the interactions of the root rot fungus Heterobasidion annosum with Scots pine (Pinus sylvestris L.) // Plant Science.-2005.-168.-P. 365-372.

14. Ковальова В. А., Гут Р. Т. Виділення білків із фунгіцидною активністю 3 проростків сосни звичайної // Физиология и биохимия культурных растений.-2007.-39, № 2 .C. $114-120$.

15. Ковальова В. А., Гут I. Т., Гут Р. Т. Характеристика двох дефензиноподібних білків з проростків сосни звичайної// Біополімери і клітина.-2006 --22, № 2.-С. 126-131.

16. Ковальова В. А., Гут Р. Т. Створення та аналіз бібліотеки генів сосни звичайної // Наук. вісн. НЛТУ України.-2007.-Вип. 17.3.-С. 30-34.

17. Ковальова В. А., Гут І. Т., Киямова Р. Г., Філоненко В. В., $\Gamma y m$ P. T. Клонування та аналіз кДНК дефензина 1 сосни звичайної // Біополімери і клітина.-2007.-23, № 5.C. $398-404$.

18. Маниатис Т., Фрич Э., Сэмбрук Дж. Методы генетической инженерии. Молекулярное клонирование.-М.: Мир, 1984.-480 c.

19. Schagger H., von Jagow $G$. Tricine-sodium dodecyl sulfate polyacrylamide gel electrophoresis for the separation of proteins in the range from 1-100 kDalton // Anal. Biochem.-1987.-166.-P. 368-379.

20. Broekaert W., Terras F., Cammue B., Vanderleyden J. An automated quantitative assay for fungal growth inhibition // FEMS Microbiol. Lett.-1990.-69.-P. 55-60.

21. Xu H., Reddy A. S. N. Cloning and expression of a PR5-like protein from Arabidopsis: inhibition of fungal growth by bacterially expressed protein // Plant. Mol. Biol.-1997.34.-P. 949-959.

22. Da-Hui L., Gui-Liang J., Ying-Tao Z., Tie-Min A. Bacterial expression of a Trichosanthes kirilowii defensin (TDEF1) and its antifungal activity on Fusarium oxysporum // Appl. Gen. Mol. Biotech.-2007.-74.-P. 146-151.

23. Thevissen K., Osborn R., Acland D., Broehaert W. Specific binding sites for an antifungal plant defensin from dahlia (Dahlia merckii) on fungal cells are required for antifungal activity // Mol. Plant-Microbe Interact.-2000.-31.-P. 54-61.

24. Osborn R., Desamblanx G., Thevissen K., Goderis I., Torrekenes S., Van Leuven F., Attenborough S., Rees S., Broekaert $W$. Isolation and characterization of plant defensins from seeds of Asteraceae, Fabaceae, Hippocastanaceae and Saxifragaceae // FEBS Lett.-1995.368.-P. 257-262.

25. Pervieux I., Bourassa M., Laurans F., Hamelin R., Seguin A. A spruce defensin showing strong antifungal activity and increased transcript accumulation after wounding and jasmonate treatments // Physiol. Mol. Plant Pathol.-2004.64.-P. 331-341.

26. Kovaleva $V$., Gout $R$. Isolation and the antifungal activity of defensin-like protein from Scots pine roots // Joint conf. UIFRO «Population genetics and genomics of forest trees: from gene function to evolutionary dynamics and conservation»: Abstract Book.-Madrid, 2006.-P. 188-189. 